\title{
The Precarity of Young People's Housing Experiences in a Rural Context
}

Drs Kim McKee, Jennifer E Hoolachan* and Tom Moore

$\underline{\text { Contact Details }}$

Dr Kim McKee (Lead author)

Centre for Housing Research

Department of Geography \& Sustainable Development

Irvine Building, North Street

University of St Andrews

Fife, KY16 9AL

Email: km410@st-andrews.ac.uk

Tel: 01334463928

Dr Jennifer Hoolachan (*corresponding author)

Cardiff School of Social Sciences

Glamorgan Building,

King Edward VII Avenue,

Cardiff University,

Cardiff, CF10 3WT

Email: HoolachanJ@ cardiff.ac.uk

Tel: 02920876871

Dr Tom Moore

Department of Urban Studies and Planning

University of Sheffield

Western Bank

Sheffield, S10 2TN

Email: tom.moore@sheffield.ac.uk

Tel: 01142228386

Accepted for publication in Scottish Geographical Journal published by Taylor and Francis. The final published version is available at: https://doi.org/10.1080/14702541.2017.1321136

\section{Acknowledgements}

This work was supported by the Leverhulme Trust under Programme Grant RP20 II-IJ-024 and the Carnegie Trust for the Universities of Scotland under Small Grant 31920. 


\title{
The Precarity of Young People's Housing Experiences in a Rural Context
}

\begin{abstract}
Young people's housing, economic and labour market circumstances have become increasingly insecure due to the combined effects of the 2007-08 economic crisis, neo-liberal welfare reforms, rising costs of higher education, and the shortage of affordable housing. Discussions of young peoples' experiences in these domains have largely neglected their spatial variability but evidence suggests that young people living in rural parts of the UK have distinctive experiences of housing, which are closely connected to labour markets and educational opportunities. By drawing on qualitative data from young people and housing professionals, this article explores some of these rural distinctions and frames them within theoretical debates about the 'precariat'. It argues for a more theoretically-informed and geographically-nuanced understanding of contemporary housing issues as rural youth potentially face greater precarity than their urban peers.
\end{abstract}

Keywords: youth; housing; rural; private rent; labour markets, precariat

\section{Introduction}

In the UK, young people's housing and employment opportunities have been compromised in the aftermath of the 2007/08 financial crisis with its accompanying neoliberal austerity measures (Kemp, 2015). The combined difficulties of securing permanent and well-paid employment, high levels of student debt, a shortage of 'affordable' housing and additional barriers to homeownership have left young people struggling to live independently (Clapham 
et al., 2014; Hardgrove, McDowell and Rootham, 2015). Consequently, many are remaining in the parental home for long periods of time, while others turn to the private rented sector (PRS); with this latter group often referred to as 'Generation Rent' (McKee, 2012; McKee et al., In Press). This is, however, a homogenising term which can mask the varied experiences of young people. For example, young people's navigations of housing and labour markets are intersected by their socioeconomic backgrounds, education levels and whether they are navigating these markets alone or with others (Furlong et al., 2003; Clapham et al., 2014).

Whilst there has been much UK and international research on young people and intragenerational housing inequalities in recent years (Druta \& Ronald, 2016; Lennartz et al., 2016) we argue there are two key limitations to this burgeoning body of work. Firstly, it is lacking in spatial nuance, and largely ignores that the housing opportunities open to young people vary geographically (for exceptions see, Hopkins, 2010; Hochstenbach \& Boterman, 2017; Hoolachan et al., 2017). Housing markets are inherently spatial, with house prices, rental costs and tenure structures varying significantly at the national, regional and local scale. More specifically, housing research has long highlighted the particular challenges faced in rural contexts (Shucksmith, 1990; Jones, 2001), yet there has been little engagement with this in contemporary research on 'Generation Rent'. Secondly, the theoretical inspiration for much of the aforementioned housing research has been informed by inter-generational justice, housing pathways and youth transitions. We argue there are also valuable insights to be gained by connecting to debates within contemporary class analysis, which highlights the growth of a 'precariat' class - united by their common experience of insecure work, income and ability to remain in their preferred place of residence (Standing, 2011; Banki, 2013; Savage, 2015).

With these issues in mind, this article argues for the importance of considering how young people's precarious housing and labour market circumstances are intersected by geography. In doing so it addresses the lack of spatial nuance in current debates about the 
housing challenges facing 'Generation Rent' by considering these challenges within rural contexts. Moreover, it seeks to expand the theoretical focus of these debates by connecting to current debates about the 'precariat'. The following two sections review the current literature in these areas. The studies that provide empirical data for this article are then introduced and subsequently the main findings are presented thematically and then discussed.

\section{The Rise of the 'Precariat' and the Spectre of 'Generation Rent'}

Contemporary class analysis highlights the growth of a 'precariat' class marked by insecurity of work and income that in turn impacts negatively on individuals' well-being, and their ability to get by. As Standing (2011) highlights, neoliberal policies have created the conditions by which a growing number of people share a common enough experience to justify labelling them an emerging class (see also Savage, 2015). Whilst Standing draws attention to the fragmented and unstable nature of labour market processes, and how this leads to a lack of a secure work-based identity, we argue precariousness is not restricted to the sphere of work. Banki (2013: 450-451), for example, has framed migration in terms of precarity, stating that 'precarity of residence does not suggest imminent deportation from a country, but its very real possibility'. Precarity, then, is about vulnerability and the potential for exploitation. Following this, we argue that precarity is also experienced in a housing context, as a growing number of British households now find themselves living in the PRS: a housing sector that is characterised by insecure, short-term tenancies ${ }^{1}$. The growth of the PRS represents a profound shift in the British housing system. It now houses more than 18 per cent of households (ONS 2014a), with that figure rising to close to 50 per cent amongst the under 35s: hence the label 'Generation Rent'. These changes reflect not only the recent decline of homeownership, which has become unobtainable for many people, but also the longer-term contraction of social housing (Murie, 
1997). After decades of relative improvement in housing access and quality in the UK, there is a danger that this going into reverse, as the PRS (which has the lowest housing standards of the three main housing tenures) expands to fill the gap once occupied by social housing. Yet there has been surprisingly little attempt to conceptualise these housing tenure shifts in terms of the broader social and economic processes giving rise to the 'precariat'.

Young people are a group hit hard by these changes. As Standing comments 'youth make up the core of the precariat' (2011: 113). Whilst much has been written about the recent rise of 'Generation Rent' in the UK (McKee, 2012; Clapham et al., 2014; Hoolachan et al., 2017; Cole, Powell \& Sanderson, 2016; McKee et al., In Press), this has largely been conceptualised in terms of inter-generational conflict, housing pathways and youth transitions. Such arguments highlight how young people have increasingly different housing opportunities and experiences to their (grand)parents (Willets, 2011; Howker \& Malik, 2013). Not only is homeownership now more difficult to achieve, due to stricter mortgage lending criteria which demand a more sizeable deposit (Clapham et al., 2014), but also access to social housing is more limited due to public sector cuts that have restricted new development and resulted in allocations policies geared towards the most vulnerable (Robinson, 2013). It is important to note, however, that legislation and regulation varies geographically, for housing policy is a devolved matter in the UK (for fuller discussion see McKee, Muir \& Moore, 2017).

The rise of 'Generation Rent' is not a product of housing shifts alone. Young people's inability to access homeownership is also due to labour market precariousness, which renders it increasingly difficult to gain and hold-down a mortgage. Not only is youth unemployment higher than for the population as a whole (Boffey, 2015), this group has been vulnerable to the rise in casualisation and part-time work affecting British labour markets (Hardgrove, McDowell \& Rootham, 2015). This, in turn, impacts on job security and income levels, which may influence young people's tenure preferences based on decisions about security and 
affordability. Housing and labour markets are, therefore, inextricably linked. They are also inherently spatial, with easy access to both housing and jobs varying in different parts of the UK. Both dimensions are vital to understanding the rise of the 'precariat'. Although there has been some discussion about private renting and 'precarity' (see Bone, 2014; Cole, Powell \& Sanderson, 2016), this has largely been as a synonym for insecurity as opposed to connecting explicitly with Standing's argument about the precariat as an emerging class.

Beyond these two critical areas there are other key factors contributing to the increasing insecurity of work and income. Young people have also been affected by rising student debt driven by increased participation in Higher Education in recent decades (Standing, 2011). Crucially, repayment of student loans undermines young people's capacity to save for a mortgage deposit, thus further delaying entry into homeownership (Andrew, 2010). In addition, young people under 35 have been hit hard by UK government welfare reform, which has reduced their eligibility for Housing Benefit (HB) support (for detailed discussion see Powell, 2015). These reforms have been compounded by more general restrictions on eligibility for social security benefits and increased welfare conditionality.

An interesting outcome of these housing, labour market and educational barriers is a growing reliance on parental support. Young people are remaining in the parental home for longer (ONS, 2014b) or they are 'boomeranging' back and forth between their parental home and independent living (Stone, Berrington \& Falkingham, 2014). Those who cannot rely on this familial safety-net are increasingly vulnerable.

The spatial differences to these new patterns of inequality have, however, yet to be fully explored. The ability of young people to access secure and affordable housing, and stable wellpaid employment, is likely to be geographically nuanced, with variations between and within urban and rural locations. Such challenges are likely induced by interrelated issues, including 
the supply, cost and availability of housing, the nature and complexities of local labour markets, and access to infrastructure and transport.

\section{The Precarity of Rural Places}

Nuancing spatiality is a complicated endeavour as it can occur at multiple scales, with different foci and is bound up in the social constructions of 'space' and 'place' (Casey, 2001; Massey, 2005). Of relevance for this paper, is a growing body of geographical literature concerned with 'precarity of place'. As Waite (2009) notes, the concept of 'precarity' has been an interest of European academics (particularly in France), long before finding its way into the English language. In the same way as Standing (2011) and other contemporary thinkers (e.g. Dorre et al, 2006; Munck, 2016) use the concept, preceding French thinkers - most notably Bourdieu (Waite, 2009) - have used 'precariat' in reference to labour market casualisation and, particularly, its effect on migrant workers across the world. Extending this work, Banki (2013) argues for labour market precarity and 'precarity of place' to be disentangled, although with the recognition that they are closely connected. Banki defines 'precarity of place' as 'vulnerability to removal or deportation from one's physical location' (2013: 453). While this is in reference to migrants, it can also be applied to the challenges facing non-migrant young people in the context of housing and, especially, the insecure PRS. We have outlined such precarity in its broader sense elsewhere (Hoolachan et al., 2017). In this paper, we further nuance these arguments by looking at precarity in rural places, primarily in relation to housing but also encompassing employment and education.

The supply of rural affordable housing has been of enduring and historical public and policy interest, dating back to limitations on rural development that were enshrined in the 1947 UK Town and Country Planning Act. Ever since, and despite various planning policy 
amendments that have sought to encourage rural development (HM Government, 2011), significant challenges remain. These include discrepancies between supply and demand for affordable housing and the exclusion of less affluent households unable to compete for scarce and expensive housing resources (Shucksmith, 1981, 1990; Sturzaker, 2010). This is compounded by the low wages that typically characterise rural labour markets and which mean local people struggle to afford housing, even in places where house prices and rental costs are below the national average (Moore, 2015).

In addition, rural markets tend to have proportionately lower stocks of social housing and a smaller PRS. This contributes to social change in rural areas whereby 'competition from commuters, retirees and second home owners' (Rural Housing Policy Review Group, 2015 p. 3) has disadvantaged and excluded those on lower incomes, who often tend to be younger people in local, low-paid employment. Rural housing markets are also affected by high rates of second-home ownership in some communities, which tends to be a highly localised issue (as shown by Gallent, Mace \& Tewdwr-Jones’ 2003 study in Wales). Limited rural housing options available to young adults can result in homelessness (Cloke, Milbourne \& Widdowfield, 2001), extended periods of residency in the parental home (Jones, 2001), or the out-migration of those who would otherwise prefer to live in rural locations (Taylor, 2008). While housing accessibility may be a driver for rural out-migration, for many young people this will also relate to a desire to pursue educational opportunities in urban areas or to improve employment prospects (Stockdale, 2002). Such opportunities can be limited due to the smallscale nature of rural labour markets, decline of agricultural industries and the remoteness of rural communities, which - coupled with poor public transport links - reduces the areas within which rural youth can work and encourages lengthy and expensive commuting patterns which also impinge on their ability to afford housing (Jones, 2001; Shucksmith, 2004). Overall, existing literature suggests that while young people in general are facing housing and 
employment precarity, these challenges may be intensified for those living in rural places. Yet, despite this evidence, spatial distinctions are often overlooked in discussions of 'Generation Rent'. This article addresses this gap by focusing attention on rural nuances that shape young people's experiences. It does so with reference to the emerging literature on the 'precariat' and 'precarity of place'.

\section{Methods}

This paper draws on qualitative data to understand the housing challenges faced by young people living in rural Scotland and England. It uses a sub-sample from two broader projects concerned with housing and inter-generational justice. Both studies sampled participants from a mix of urban and rural locations in an attempt to capture place-specific nuances, with the rural data being the focus of this paper. Geography, was however, only one dimension of the projects' wider remit and conceptual focus.

\subsection{Study 1}

Funded by the Leverhulme Trust, Mind the (Housing) Wealth Gap, investigated processes of inter-generational justice and wealth transfer between family members. The data extracted from this project were derived from one work-stream, which focused on the role of family support in shaping young people's (aged 18-35) housing opportunities. Ten synchronous focus groups (see Moore, McKee \& McLoughlin, 2015 for more detail) and 31 semi-structured telephone interviews were conducted with 62 young people in 2013-14. Participants were recruited from 8 UK case study areas (Cornwall, Sheffield, Surrey, Edinburgh, North Lanarkshire, Scottish Borders, Belfast and Merthyr Tydfil), which provided an urban-rural mix, 
as well as enabling sensitivity to devolved policy contexts across the UK. For more detail on the research design, please see the project website (Soaita \& McKee, 2015).

\subsection{Study 2}

The second follow-up study titled Housing Generation Rent: What are the Challenges for Housing Policy in Scotland? was funded by the Carnegie Trust for the Universities of Scotland. It used purposive sampling to explore the expert knowledge of 19 key-actors from 11 voluntary and private sector organisations (e.g. Shelter, Rural Housing Scotland, National Union of Students, Citizens Advice Scotland), as well as four local authority housing departments (Aberdeen City, Dundee City, Fife and the Scottish Borders). These individuals were recruited due to having professional knowledge of Scotland's housing situation and the challenges facing young people. Local authorities were chosen based on obtaining an urban-rural mix as well as capturing demographic and housing market diversity. During 2015, semi-structured interviews were conducted with 16 people. For more details on the sampling strategy and methodology see McKee \& Hoolachan (2015).

\subsection{Sample characteristics}

Given this paper prioritises the voices of those with knowledge and experience of housing challenges in rural areas this reduces the size of the sample drawn upon here in our analysis.

In Study 1, the 'rural voice' was provided by those young people living in the Scottish Borders and Cornwall. Of the 62 young people sampled in Study 1, 6 lived in the Scottish Borders and 11 lived in Cornwall. Thus, 17 young people are represented in this paper. The Scottish Borders is a large local authority area situated on the border between Scotland and 
England. It contains areas in the north that serve commuters working in Edinburgh (Scotland's capital city). The living costs in these commuter belts are typically higher in comparison to other (more remote) parts of the local authority. In addition, the local authority contains areas clustered with second/holiday homes. Thus, the Scottish Borders contains a mixture of populated towns, tourist 'hotspots' and remote villages meaning the labour and housing markets vary. Cornwall, on the other hand, is a coastal local authority in the south west of England. Its stock of social housing is lower than the national average and so private housing (ownership and renting) is the dominant tenure. It is a popular tourist destination and contains a sizeable proportion of second/holiday homes.

While in economic terms, the Scottish Borders and Cornwall are comparable (ONS, 2016), as with most places they are geographically, politically and culturally distinctive. Borrowing a term from Macintyre, Ellaway and Cummins' (2002), the emphasis in this paper is on 'contextual' aspects of place in the sense that its focus is on opportunity structures, and as such the 'thick' detail concerning distinctive sociocultural features is of secondary interest. This is not to say that sociocultural significance is irrelevant (far from it), however, as will be seen from the data, there are important themes that cut across the rural case study areas which we wish to highlight.

Of the 19 key-actors in Study 2, six were able to discuss rural issues in detail. Working in local authorities or voluntary sector organisations linked to housing meant that the key-actors could draw on their professional experiences, knowledge and their familiarity with housing policy and practice. In each interview, the key-actors were asked if such professional experience would enable them to provide knowledge on rural-specific issues. The six keyactors selected for this paper were those who responded favourably to this question. 
In summary, the total number of participants who informed this paper is 23 (17 young people and 6 key-actors). To protect their identity, pseudonyms have been used for the young people from Study 1, and 'key-actor' has been used when representing those in Study 2.

\subsection{Analysis}

The qualitative data from the 23 participants were imported into NVivo 10 (software for assisting with qualitative data analysis), and analysed thematically according to the principles of Constructivist Grounded Theory (Charmaz, 2014). This approach develops theoretical arguments in an empirically grounded, inductive fashion and it draws attention to the socially constructed nature of knowledge and the positionality of the researcher. Despite drawing on data from two separate qualitative studies, there were common issues arising in relation to the particular challenges faced by young people living in rural areas. It is these bottom-up codes, which have been developed through sensitivity with both the data and the literature, that underpin the arguments put forward in this article. We regard this paper as a starting point, as we have reflected upon in the conclusion, with further empirical research required to disentangle the particular rural challenges facing contemporary youth. The sections that follow turn to our analysis of the empirical data.

\section{Findings}

\subsection{Insecure times: educational and labour market opportunities for rural youth}

Consistent with the literature, our findings indicate that opportunities for young people in rural areas were lacking in comparison to larger towns and cities. Not only were job opportunities 
generally limited, participants highlighted a lack of well-paid, full-time, permanent positions as they perceived most jobs to be low-income and on a part-time and/or fixed-term basis:

The job market is more competitive and down here it's... saturated, is not the right word but there just aren't 'big money jobs' out there. (Stuart, 29, Cornwall, Home owner)

A lot of the volume jobs have been lost to the Pacific rim [...] a lot of these jobs have gone on a one-way ticket and won't come back. (Key-actor 1, referring to Scottish Borders)

In other words, there were few stable opportunities available which would provide the financial security to 'settle down' in one place (Hoolachan et al., 2017). This sense of insecurity, and the ability to find and stay in work, is a defining feature of Standing's (2011) precariat, with instability in the labour market having knock on effects in other areas of people's lives:

For the last ten years I've been going job to job, you know, cleaning [...] it's a hand to mouth existence. (Sophie, 27, Cornwall, Social Housing)

Just having that foundation that you, even though you could become redundant or lose your job, just even having a contract where you think there's some chance that you can stay there and sort of settle a bit, I think that would make a huge difference. (Katie, 26, Cornwall, Private Tenant) 
These extracts point to the connection between financial and ontological security (Giddens, 1991). Having a regular income does not simply provide a means of affording to live, it enables feelings of certainty and stability which some of our participants highlighted as important for their wellbeing. Furthermore, quotes such as these relate to one of the most fundamental changes in the youth labour market in recent years that many are, 'experiencing status frustration, feeling economically insecure and unable to see how to build a career' (Standing 2011: 132). Evidence suggests that this issue of low-skilled and low-paid work is more prevalent in rural areas that have historically been characterised by a smaller-scale job market (Shucksmith, 2004).

Education opportunities were also frequently discussed, as young people living in rural areas had to make decisions about their anticipated career paths and whether or not they would attend university. Given that universities are typically concentrated in urban areas, a decision to attend university was often a decision to leave the area in which they had grown up in. Consistent with the existing literature (Stockdale, 2002) this issue came across strongly in our data as several young people had already made this decision or were in the midst of doing so. Again, the lack of attractive job opportunities was highlighted. While some wanted to move away from their rural homes and others appeared to accept this as an inevitability, there was evidence that others did not want to leave, but felt compelled into doing so because of the challenges of local (rural) labour markets. This came across strongly among the young people from Cornwall who, more than others, expressed strong feelings of place attachment:

I mean I love Cornwall, that's the thing. I wouldn't particularly want to move away from Cornwall; it's my home. (Catriona, 32, Cornwall, Private Tenant) 
Thus, while some young people engaged in processes of out-migration, others were emotionally attached to their rural homes meaning they made conscious decisions to stay. Taking these findings together, analysis of the qualitative data indicated three broad education/employment/housing transitional experiences of the young people in our study: (1) leaving their rural home for the cities and not returning; (2) leaving their rural home for university and then returning upon completion of their degrees; and (3) not leaving their rural home and not attending university. Young people in the two latter groups were dependent on their local labour (and housing) markets. Jones (2001) has noted that those who choose to remain in rural areas are highly likely to be earning low wages and in insecure employment thus experiencing a more 'precarious' existence. In our data, similar issues were highlighted specifically in relation to young people living in Scotland's island communities:

Well probably the biggest issue is that island income tends to be a lot lower compared to inland and [if you were to look at unemployment figures on the island] they would look so low because people either are too ashamed to claim benefits or $[\ldots]$ they have a Guest House [which only makes money in the summer] and you quite often find people working two or three different jobs just to make ends meet. (Key-actor 6, referring to Scotland's island communities)

In addition to job insecurity, this participant highlighted the low levels of uptake of social security benefits by unemployed islanders. She explained that there was an element of shame in receiving welfare support; a feeling that some academics argue is encouraged by neoliberal media outlets as a means of legitimising welfare cutbacks (see Hill, 2014 for example). The participant also surmised that the physical location of Job Centres on the mainland were also reasons for low benefit uptake. At the same time, she drew attention to the 
strong sense of community, which meant that neighbours often supported each other in times of financial difficulty.

In contrast to these struggles, some of the Cornish young people described how a few of their friends had used their entrepreneurial skills to start their own businesses in order to build a life for themselves locally:

One of my friends owns a brewery [...] so he's done very well [...] My best friend as well, she had her own business for three years which somehow thrived in a tiny village. I think they've done extremely well and they don't really know how they've done it [...] I think in Cornwall, I don't know if there's... maybe it's the community aspect that there's more support and then once a good idea appears people will really support it and help it to grow. (Katie, 26, Cornwall, Private Tenant)

It appeared that having a 'sense of community' in the form of everyone supporting each other during times of unemployment or a new business venture was crucial for ensuring that people could meet their living costs. This is consistent with literature that describes how local businesses can facilitate social cohesion and resilience in rural communities (Steiner \& Atterton, 2015). Nonetheless, the majority of participants agreed that there were insufficient opportunities in rural areas to ensure that young people could earn an adequate and consistent income that would enable them to live independently in housing that met their needs. The reality of ever rising rents, coupled with low and insecure incomes undermined their ability not only to realise their housing aspirations, but also to forge a stable and successful 'career'.

\subsection{Precarious rural housing markets}


Within the rural settings of our case study areas (Scottish Borders and Cornwall), the young people in Study 1 placed great emphasis on the lack of available housing supply in their local areas. Specifically, they asserted that not only can it be difficult to find a suitable property to buy or rent in their preferred location, it is even harder to find somewhere that is 'affordable'. These discussions were also interlinked with comments about low wages, as the young people's definitions of 'affordable' were subjective and relative to their incomes:

I've looked at places around the Borders and there just seems to be nothing round here like in my budget. (Kayleigh, 19, Scottish Borders, Living with Parents)

House prices in Cornwall are disproportionate to the average wages. House prices are inflated by second home owners as well as people buying property to let out as holiday accommodation. 'Affordable housing' tends not to be actually affordable for people. (Rebecca, 34, Cornwall, Home owner)

This highlights how an understanding of the housing challenges needs to be considered in tandem with structural changes in contemporary labour markets - fusing an analysis of people's employment and housing situations. This requires going beyond Standing's (2011) focus on insecure jobs and incomes alone. Housing, we argue, is a further critical yet often neglected dimension. Not least as housing costs are often the largest household expenditure for most people, and so is inextricably linked to income.

Yet understanding these housing issues requires geographical sensitivity, for geography can be a significant mediator of subjective experience of the housing market. For example, the participants in our studies all noted the difficulties that second/holiday homes in rural areas can cause for long-term local residents - a finding reverberated in the wider policy and academic 
literature (Jones, 2001; Rural Housing Policy Review Group, 2015). These were generally viewed as problematic as not only do they drive up property and rental costs, noted by Rebecca above, they further reduce the housing stock for locals. One key-actor explained that some of these second/holiday properties are available to rent by locals during the off-peak winter months. As the owners typically do not live in these properties in the winter and they are unlikely to attract any tourists, the rent levels are reduced making them more affordable for local people. However, these lets are characteristically seasonal meaning the locals need to move out in the spring as the owners either wish to spend the summer there or, more commonly, rent out the property to tourists at substantially higher rates. In the meantime, local people either need to leave the area to find 'affordable' accommodation further afield, or some live in caravans during the summer months. As the key-actor noted, since it is more lucrative for second/holiday homeowners to rent their properties to seasonal tourists, there is no incentive for them to contribute to the provision of housing for local residents. This has significant implications for the sustainability of rural communities, and people's ability to put down roots and make a home.

Such problems were reiterated by some of the young people who also felt that, in some places, second/holiday homes had compromised local feelings of community:

We can't avoid the fact that a lot of the houses that families lived in when I grew up are now second homes. Even if I could afford to live in that village, it would be hard trying to find a place that's not somebody's second home! It's definitely had an impact on prices of houses and rent, and the community itself, the fact that these second homeowners are moving in and prising us out a bit. (Sophie, 27, Cornwall, Social Housing) 
Notions of 'community' were mentioned in the previous section as they related to local support during times of unemployment or when starting a new business. Sentiments like Sophie's, though, were more akin to the 'loss of community' thesis which purports that, through processes of gentrification, rural communities are weakened and local residents are priced-out of the market due to the growth in second-homes (Coppock, 1977 in Gallent, 2014). In our data, additional understandings of community were captured through young people's statements about wishing to "settle down" or "put down roots" by being able to socially invest in, and benefit from, their communities. Settling down was dependent on living in secure housing and several young people struggled to achieve this due to the combined effects of income instability, and their reliance on the PRS which is characterised by tenancy contracts that enable landlords to tell their tenants to leave at the end of the contractual period (Hoolachan et al., 2017) ${ }^{1}$. Such insecurity meant that some were unable or unwilling to fully settle in their local communities as there was a likelihood of having to move again at short notice:

But there's always that worry that it's not your home and you could get asked to leave at any time $[\ldots]$ if in ten years we have children and things like that, it would bother me that I didn't own my own home then because I want somewhere with a bit of security. (Lorraine, 26, Cornwall, Private Tenant)

While this issue was raised by both urban and rural participants (see Hoolachan et al., 2017), second/holiday homes in rural areas added to the difficulties young people had in 'settling down' as they reduced supply and contributed to high rental costs. In recognition of these issues, some local authorities have taken steps to restrict second/holiday homes in particular areas (Rural Housing Policy Review Group, 2015), but our data suggest that it remains a concern for some rural communities. As can be seen from this section, 'precarity' 
does not only relate to income insecurity as Standing (2011) theorises; it also manifests as housing insecurity due to problems of affordability and instability. Although these issues are pervasive across different parts of the UK (Cole, Powell and Sanderson, 2016; Hoolachan et al., 2017), they have a distinctive hue when considering them in a rural context. 'Precarity of place' (Banki, 2013), then, not only applies to the vulnerabilities experienced by migrants, it can also be interpreted as the unstable and exclusionary opportunity structures which young people living in rural parts of the UK are facing and which are key drivers of the 'precariat' class (Standing, 2011).

\section{Discussion and Conclusion}

The rise of 'Generation Rent' has been well documented in academic research over the last decade. Whilst there is wide agreement this phenomenon rests within a complex web of housing, employment and financial vulnerability, there is a notable lack of geographical sensitivity to these arguments. Yet as our qualitative data highlights, young people living in rural areas can be additionally disadvantaged. Many struggled to access well-paid, stable employment making it difficult to establish and sustain a career, and generate the level and security of income required to realise their housing aspirations. This resulted in some having to leave their rural homes for urban areas that provide greater opportunities. Those young people who remained felt they were being 'prised out' because of a lack of affordable housing, which was compounded by the prevalence of second-home owners. This not only undermined their strong attachment to place, and compromised the sustainability of local communities, but it also resulted in many young people having to remain in the parental home for longer or alternatively to try and navigate an expensive, unregulated and (often) insecure PRS. 
Youth researchers have typically tried to understand these issues with reference to theories about inter-generational justice, housing pathways or youth transitions. We argue there are additional conceptual insights to be gained by taking influence from contemporary class analysis, specifically the rise of 'the precariat' (Standing, 2011; Savage, 2015). The emphasis on insecurity of jobs and income, is highly relevant, with our qualitative data highlighting the harsh reality that many young people feel they have potentially no sense of building a career in rural communities. Instead, they face a much more transient and insecure existence: moving from one low-paid, temporary job to another. This not only creates a sense of uncertainty, but as we have argued elsewhere (Hoolachan et al., 2017), it also generates frustration amongst young people who feel they are being denied the type of opportunities that their parents and grandparents enjoyed. For 'Generation Rent' reaching the adult-milestones of leaving the parental home, building a career and starting a family is a much more protracted and challenging process. Whilst Standing (2011) comments that this situation may lead to people becoming disaffected and disenfranchised from society, it may be reversed by increasing participation in public life and improving housing and job opportunities. Whilst it is beyond the scope of this paper to offer such policy recommendations, as we have argued elsewhere, spatial nuance is also vital to understanding housing policy making in the UK given it is a devolved matter (McKee, Muir \& Moore, 2017).

Not only do the findings in this paper advance the literature on 'Generation Rent' through its application of Standing's (2011) insights and its focus on rural nuance, it also has implications for the work of Banki (2013) and wider geographical literature concerned with 'precarity of place'. Banki’s (2013: 454) work on migration, colonialism and neoliberalism led her to argue that precarity of place ' $[\ldots]$ describes the condition of not quite homeless, not yet deported or detained'. Furthermore, she notes that precarity of place has theoretical traction in other areas of life characterised by a lack of security and its day-to-day impacts. We argue 
that the rural challenges discussed in this paper offer an additional area in which Banki's arguments can be explored and applied. None of the young people represented in this paper were homeless but their jobs and homes were not secure in the longer-term. This was not only a reflection of the neoliberal context that currently dominates the Western world and within which the precariat has grown, it was also a contextual feature of rural places where the opportunities for security are low. Precarity of place, then, was operating at two levels: at the level of the housing system in its wider sense; and at the level of rural geography. The young people in our research were caught at the intersection of these two levels which served to increase the challenges they were exposed to.

In addition, the arguments presented in this paper have implications for countries outside of the UK in two ways. First, the increasing precarity that young people face in relation to labour and housing markets is far from unique to the UK. When looking comparatively, such insecure conditions have been reported in Australia, China, Japan, and across Europe (Antonucci and Hamilton, 2014; Forrest and Yip, 2013). Thus, the picture presented in this paper is only one part of a global phenomenon in which theories of the 'precariat' and 'precarity of place' can be applied. Secondly, international efforts to understand such challenges have not only involved between-country comparisons, they have also looked inward to investigate the spatial nuances within a country, just as we have done in this paper. In doing so, it would appear that rural conditions are distinctive in multiple and complex ways. For example, when investigating young Finnish people's attitudes towards the prospect of living in the countryside in the future, Kuhmonen, Kuhmonen and Luoto (2016) noted that despite the mass out-migration of young people from rural communities, many of their participants viewed these same communities as idyllic and desirable places to live in the future. Thus, they argued, it is beneficial to account for these attitudes when designing rural development policies. Moreover, while these authors urged caution when generalising their 
findings, given the specific 'biophysical, economic, social and cultural fabrics of each country and location' (Kuhmonen, Kuhmonen and Luoto, 2016: 99), they likewise stated the value in comparing similarities and differences between countries at both macro and micro-scalar levels. The current paper, then, is useful for making such comparisons and for raising the profile of rural studies more generally.

Whilst this article achieves our aim of refocusing attention on the importance of geography in discussions of 'Generation Rent', to fully unpack the nuanced experiences of young people would require a larger stratified sample drawing on participants from a wider range of rural contexts to consider socio-spatial variation. This is important given that rural areas contain housing options that are not as typically found in urban areas such as Community Land Trusts, crofting and self-build (Morgan \& Satsangi, 2011; Moore, 2015). Furthermore, housing strongly overlaps with land ownership and this is salient within rural contexts as private land owners exert great influence over housing and community development (McKee, 2015). Widening the sample and scope of future research would enable these specifically rural tenures and land issues to be accounted for in the context of youth housing experiences. In addition, our data did not strongly capture the experiences of young people in receipt of social security benefits, and given statements by one key-actor that shame can preclude people in some rural areas from claiming benefits, it would be interesting to unpack this further. This is pertinent in the current context of extensive UK welfare reform, which has hit young people particularly hard (Cole, Powell \& Sanderson, 2016) and is highly relevant when considering those who might form the 'precariat' class (Standing, 2011).

Overall, this article is a starting point in highlighting the particularity of rural contexts; there is still more to be done to build our understanding of the complexity of the challenges affecting young people in such places. Such arguments about the need for more fine-grained geographical analysis have broader international resonance beyond the UK context. 


\section{References}

Andrew, M. (2010) The changing route to owner-occupation: the impact of student debt, Housing Studies, vol. 25(1), pp. 39-62.

Antonucci, L. and Hamilton, M. (2014) Youth transitions, precarity and inequality and the future of social policy in Europe. In. L. Antonucci, M. Hamilton and S. Roberts (eds) Young people and social policy in Europe (Basingstoke: Palgrave MacMillan Ltd.).

Banki, S. (2013) Precarity of place: a complement to the growing precariat literature, Global Discourse, vol. 3(3-4), pp. 450-463.

Boffey, D. (2015) 'Youth unemployment rate is worst for 20 years, compared with overall figure', The Guardian, 22 February [Online] Available at: https://www.theguardian.com/society/2015/feb/22/youth-unemployment-jobless-figure

Bone, J. (2014) Neoliberal Nomads: housing insecurity and the revival of private renting in the UK, Sociological Research Online, vol. 19(4), 1.

Casey, E.S., (2001) Body, self and landscape. In. P.C. Adams, S. Hoelscher and K.E. Till eds. Textures of place: exploring humanist geographies (Minneapolis: University of Minnesota Press. Ch. 25).

Charmaz, K. (2014) Constructing Grounded Theory (London: Sage). 
Clapham D., Mackie, P., Orford, S., Thomas, I., \& Buckley, K. (2014) The housing pathways of young people in the UK, Environment and Planning A, vol. 46, pp. 2016-2031.

Cloke, P., Milbourne, P. \& Widdowfield, R. (2001) Interconnecting housing, homelessness and rurality: evidence from local authority homelessness officers in England and Wales, Journal of Rural Studies, vol. 17, pp. 99-111.

Cole, I., Powell, R. \& Sanderson, E. (2016) Putting the squeeze on "Generation Rent": housing benefit claimants in the private rented sector - transitions, marginality and stigmatisation, Sociological Research Online, vol. 21(2), 9.

Dorre, K., Kraemer, K., and Speidel, F. (2006) The increasing precariousness of the employment society - driving force for a new right-wing populism? 15th Conference of Europeanists, Chicago, IL, March 30-April 2, 2006.

Druta, O. \& Ronald, R. (2016) Young adult's pathways into homeownership and the negotiation of intra-family support: a home, the ideal gift, Sociology (Online Early).

Forrest, R. and Yip, N.M. (2013) Young people and housing: transitions, trajectories and generational fractures (Abingdon: Routledge).

Furlong, A., Cartels, F., Biggart, A., Sweeting, H. \& West, P. (2003) Youth Transitions: Patterns of Vulnerability and Processes of Social Inclusion (Edinburgh: Scottish Executive Social Research). 
Gallent, N. (2014) The social value of second homes in rural communities, Housing, Theory and Society, vol. 31(2), pp. 174-191.

Gallent, N., Mace, A. \& Tewdwr-Jones, M. (2003) Dispelling a myth? Second homes in rural Wales, Area, vol. 35(3), pp. 271-284.

Giddens, A. (1991) The Consequences of Modernity (Cambridge: Polity Press).

Hardgrove, A., McDowell, L. \& Rootham, E. (2015) Precarious lives, precarious labour: family support and young men's transitions to work in the UK, Journal of Youth Studies, vol. 18(8), pp. 1057-1076.

Hill, D.W. (2014) Class, trust and confessional media in austerity Britain, Media, Culture and Society, vol. 37(4), pp. 566-580.

HM Government (2011) 'Localism Act 2011', [Online] Available: http://www.legislation.gov.uk/ukpga/2011/20/contents/enacted

Hoolachan, J., McKee, K., Moore, T. \& Soaita, A. (2017) “Generation Rent” and the ability to 'settle down': economic and geographical variation in young people's housing transitions, Journal of Youth Studies, vol. 20(1), pp. 63-78.

Hochstenbach, C. \& Boterman, W.R. (2017) Intergenerational support shaping residential trajectories: young people leaving home in a gentrifying city, Urban Studies, vol. 54(2), pp. $399-420$. 
Hopkins, P.E. (2010) Youth, Place and Identity (London: Routledge).

Howker E. \& Malik, S. (2013) Jilted Generation: How Britain has Bankrupted its Youth (London: Icon Books).

Jones, G. (2001) Fitting homes? Young people's housing and household strategies in rural Scotland, Journal of Youth Studies, vol. 4(1), pp. 41-62.

Kemp, P.A. (2015) Private renting after the global financial crisis, Housing Studies, vol. 30(4), pp. 601-620.

Kuhmonen, T., Kuhmonen, I. and Luoto, L. (2016) How do rural areas profile in the futures dreams by the Finnish youth? Journal of Rural Studies, vol. 44, pp. 89-100.

Lennartz, C.; Arundel, R. \& Ronald, R. (2016) Younger adults and homeownership in Europe through the Global Financial Crisis, Population Space and Place, vol. 22(8), pp. 823-835.

Macintyre, S., Ellaway, A. and Cummins, S. (2002) Place effects on health: how can we conceptualise, operationalise and measure them? Social Science and Medicine, vol. 55, pp. 125-139.

Massey, D. (2005) For space (London: SAGE Publications Ltd.). 
McKee, A.J. (2015) Legitimising the laird? Communicative Action and the role of private landowner and community engagement in rural sustainability, Journal of Rural Studies, vol. 41, pp. 23-36.

McKee, K. (2012) Young people, homeownership and future welfare, Housing Studies, vol. 27(6), pp. 853-862.

McKee, K.; Moore, T.; Soaita, A.; and Crawford, J. (In Press) 'Generation Rent' and the Fallacy of Choice, International Journal of Urban and Regional Research.

McKee, K. \& Hoolachan, J.E. (2015) Housing Generation Rent: what are the key challenges for housing policy in Scotland? (St Andrews: Centre for Housing Research).

McKee, K., Muir, J. \& Moore, T. (2017) Housing Policy in the UK: the importance of spatial nuance, Housing Studies, vol. 32(1), pp. 60-72.

Moore, T. (2015) The Motivations and Aspirations of Community Land Trust Volunteers in Somerset, Dorset and Devon (Somerset: Wessex Community Assets).

Moore, T., McKee, K. \& McLoughlin, P. (2015) Online focus groups and qualitative research in the social sciences: their merits and limitations in a study of housing and youth, People, Place and Policy, vol. 9(1), pp. 17-28.

Morgan, J. \& Satsangi, M. (2011) 'Reaching the parts other grants don't go?' Supporting selfprovided housing in rural Scotland', Housing Studies, vol. 26(4), pp. 615-628. 
Munck, R. (2016) The precariat: a view from the South, Third World Quarterly, vol. 34(5), pp. 747-762.

Murie, A. (1997) The social rented sector, housing and the welfare state in the UK, Housing Studies, vol. 12(4), pp. 437-461.

ONS (2014a) 'Trends in the United Kingdom housing market' [Online], Available at: http://www.ons.gov.uk/ons/dcp171766_373513.pdf

ONS (2014b) 'Large increases in 20 to 34-year olds living with parents since 1996' [Online], Available at: http://www.ons.gov.uk/ons/rel/family-demography/young-adults-living-withparents/2013/sty-young-adults.html

ONS (2016) Regional gross value added (income approach), UK: 1997-2015 [Online], Available at: https://www.ons.gov.uk/economy/grossvalueaddedgva/bulletins/regionalgrossvalueaddedinco meapproach/december2016\#what-was-the-average-gva-in-your-local-area

Powell, R. (2015) Housing Benefit reform and the private rented sector in the UK: on the deleterious consequences of short-term, ideological 'knowledge', Housing, Theory and Society, vol. 32(3), pp. 320-345.

Robinson, D. (2013) Social housing in England: testing the logics of reform, Urban Studies, vol. 50(8), pp. 1489-1504. 
Rural Housing Policy Review Group (2015) 'Affordable housing: a fair deal for rural communities' [Online], Available at: http://hastoe.com/page/772/Affordable-Housing-A-FairDeal-for-Rural-Communities.aspx

Savage, M. (2015) Social Class in the $21^{\text {st }}$ Century (Pelican Books: Milton Keynes).

Shucksmith, M. (1981) No Homes for Locals? (Gower: Aldershot).

Shucksmith, M. (1990) Housebuilding in Britain's Countryside (London: Routledge).

Shucksmith, M. (2004) Young people and social exclusion in rural areas, Sociologia Ruralis, vol. 1, pp. 43-59.

Soaita, A. \& McKee, K. (2015) 'Mind the (Housing) Wealth Gap findings from WS4: young people - tenure choices and welfare' [Online], Available at: http://wealthgap.wp.standrews.ac.uk/files/2013/02/End-Briefing_WS4.pdf

Standing, G. (2011) The Precariat: the new dangerous class (London: Bloomsbury).

Steiner, A. \& Atterton, J. (2015) Exploring the contribution of rural enterprise to local resilience, Journal of Rural Studies, vol. 40, pp. 30-45.

Stockdale, A. (2002) Out-migration from rural Scotland: the importance of family and social networks, Sociologia Ruralis, vol. 42(1), pp. 41-64. 
Stone, J., Berrington, A. \& Falkingham, J. (2014) Gender, turning points, and boomerangs: returning home in young adulthood in Great Britain, Demography, vol. 51(1), pp. 257-276.

Sturzaker, J. (2010) The exercise of power to limit the development of new housing in the English countryside, Environment and Planning A, vol. 42, pp. 1001-1016.

Taylor, M. (2008) Living Working Countryside: The Taylor Review of Rural Economy and Affordable Housing (London: Department for Communities and Local Government).

Waite, L. (2009) A place and space for a critical geography of precarity? Geography Compass, vol. 3(1), pp. 412-433.

Willetts, D. (2011) The Pinch: How the Baby Boomers took their Children's Future-And Why They Should Give it Back (London: Atlantic Books).

\footnotetext{
${ }^{1}$ The implications of tenure insecurity on people's ability to create a home was one of the drivers for the Private Housing (Tenancies) (Scotland) Act 2016, which affords private tenants greater security of tenure. For further details, including a comparison with legislation elsewhere in the UK see McKee, Muir and Moore 2016.
} 